\title{
CONSORT
}

TRANSPARENT REPORTING of TRIALS

\section{CONSORT 2010 Diagram}

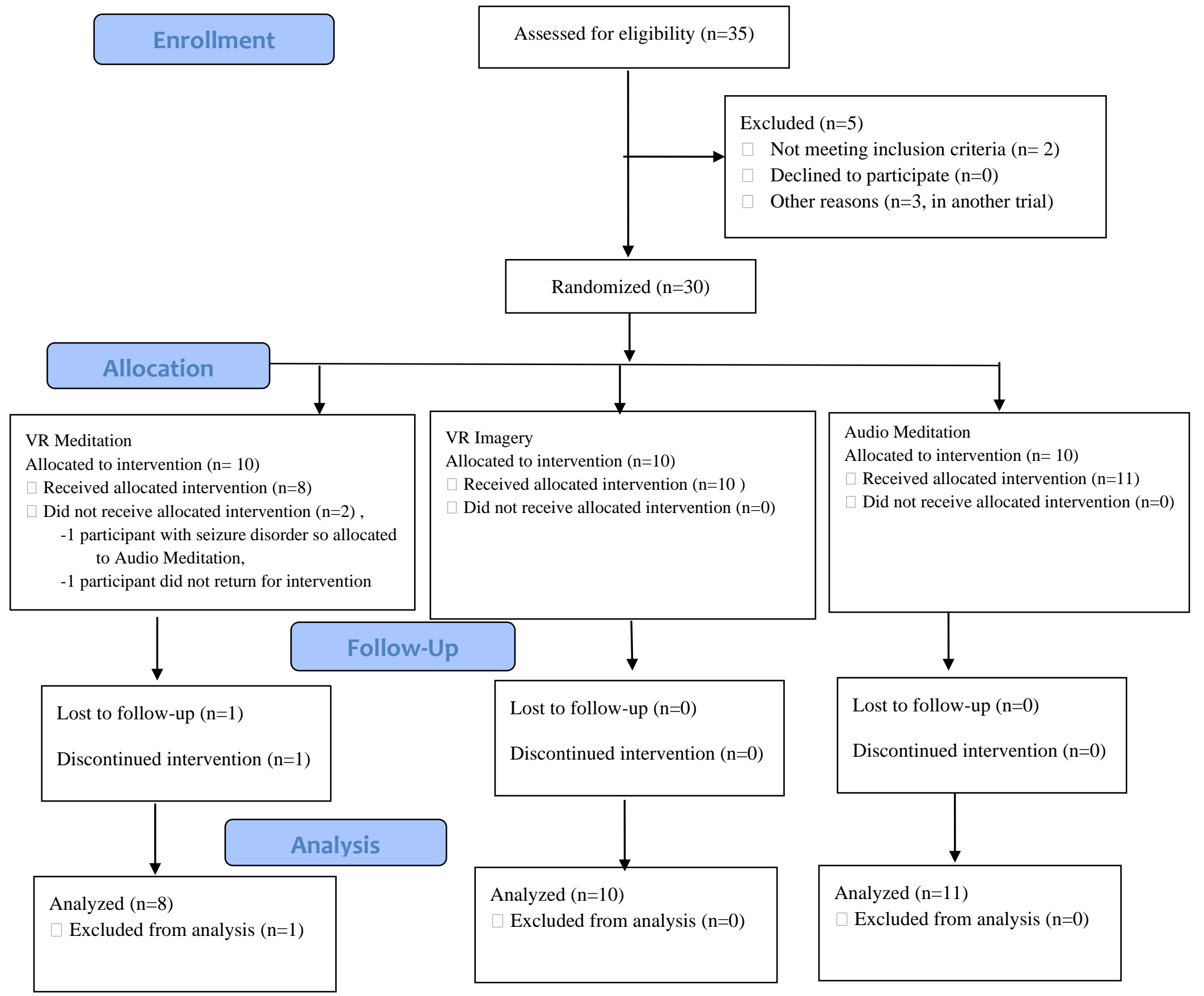

